\title{
SUPPLEMENT
}

\section{The International Court of Justice}

\section{Efficiency of Procedures and Working Methods}

Report of the Study Group established by the British Institute of International and Comparative Law as a contribution to the UN Decade of International Law

D. W. Bowett, J. Crawford, I. Sinclair, A. D. Watts

THE BRITISH INSTITUTE OF INTERNATIONAL

AND COMPARATIVE LAW

1996 
Published by

The British Institute of International and Comparative Law

17 Russell Square, London WC1B 5DR

Tel. 0171-636 5802 Fax 0171-323 2016

CThe British Institute of International and Comparative Law, 1996

ISBN 0903067609

All rights reserved. No part of this publication may be reproduced or transmitted in any form or by any means, electronic, mechanical, photocopying, recording or otherwise, or stored in any retrieval system of any nature without the written permission of the publisher. 


\section{PREFACE}

The present Supplement is published with the first part of Volume 45 of the International and Comparative Law Quarterly in January 1996. It consists of a report prepared by a study group established by the British Institute of International and Comparative Law which has examined the procedures and working methods of the International Court of Justice. The publication of the report as a supplement to the International and Comparative Law Quarterly reflects a practice which the Institute has adopted in the past in preparing occasional supplements on topics of particular importance.

The present study group was established in September 1993 on the initiative of the Public International Law Section of the Advisory Board of the Institute. The Advisory Board, which is divided into sections which reflect the Institute's areas of specialism, advises on the Institute's work programme and the way in which research on topical issues may be conducted.

The publication of the present report is intended to fulfil a threefold purpose. First, to provide a report of a study group comprised of experts with specialist knowledge and experience of the procedures and working methods of the International Court of Justice.

Secondly, to provide an example of the working methods of the Institute as a body committed to the analysis of the operation of law in practice and a bridge between academic and practising lawyers. The report contains careful analysis of the present position and specific recommendations which are intended to contribute to improvements.

Thirdly, the report represents a contribution by the Institute to the United Nations Decade of International Law. Publication arises at the midpoint of the Decade and it is particularly appropriate that this should coincide with the forthcoming 50th Anniversary of the establishment of the International Court of Justice. To mark this occasion, the Institute proposes to hold a conference on 23 and 24 February 1996 to examine the report and the work of the Court.

The Institute is most grateful to all those who have contributed to the work of the study group and especially to the authors of this report. It is hoped that publication of the supplement followed by the conference will provide readers of the International and Comparative Law Quarterly and members of the Institute with an opportunity to discuss and develop the analysis and proposals which the report contains.

\section{J. P. Gardner}

Director

The British Institute of International and

London

Comparative Law

December 1995 
https://doi.org/10.1017/S0020589300060048 Published online by Cambridge University Press 